\title{
Tennessee Williams in the 50s: A Mirror Competing Discourses
}

\author{
Ghandeharion, A. $^{1^{*}}$ and Anushiravani, A. ${ }^{2}$ \\ ${ }^{1)} \mathrm{Ph} . \mathrm{D}$. Candidate of English Literature, Shiraz University, Shiraz, IRAN \\ e-mails: azraghandeharion@gmail.com \\ ${ }^{2)}$ Associate Professor of Comparative Literature, Shiraz University, Shiraz, IRAN \\ e-mail: anushir@shirazu.ac.ir \\ * Corresponding author
}

\begin{abstract}
This article was a study of different but synchronized discourses mirrored in Tennessee Williams's Hollywood adaptations in the 50s. It discussed the effect of artistic agencies of censorship on the hows and whys of Willaims's adaptations. Most notably, PCA and HUAC were in charge of cultural and political regulations that no Hollywood film was immune from. Until the early 60, HUAC and PCA imposed religious values to supplant Communism, happy ending to replace the intellectual fad of pessimism and strict dressing code to restore the innocence of the Freud-conscious moviegoers. However, these agencies were not omnipotent. The voice of those discourses that the agencies were fighting against were heard in Hollywood. Hollywood achieved the subversion with the help of William's controversial plots albeit tamed by some reinforcing discourses of optimism and diluted religious values.
\end{abstract}

Key words: Tennessee Williams, Hollywood Adaptation, Discourse, Censorship, Ideology, New Historicism.

\section{INTRODUCTION}

Williams's fame in the course of cinematic representation was mostly restricted to his adaptation in Hollywood of the 50s and early 60s. The fan magazines of the 50s and the popular-culture internet sites stated that it was Hollywood's loudspeaker that made Williams's voice heard ("1950's Famous People"; Bradley, 2011). In literature books, the story was upside down: it was Williams who brought class and sophistication to Hollywood's entertaining simplemindedness (Palmer \& Bray, 2009, pp. 21-32; Hirsch, 1979, p. 105).

Expectedly, the movie-crisis era of the 50s, pushed big Hollywood studios like MGM, Warner Bros., Colombia Pictures, Paramount Pictures and Twentieth-Century Fox to court seriously with Williams for film rights over the financially successful plays like The Glass Menagerie (1945), A Streetcar Named Desire (1947), The Rose Tattoo (1951), Cat on a Hot Tin Roof (1955) and.... Highly motivated by the pre-sold qualities of the film, the studios didn't even wait for the plays to go off the stage. The case of Glass Menagerie was a battlefield for MGM and Warner Bros. In the end, Warner Bros., whose letter archive since 1948 showed the instant struggle for buying the rights, could win Glass
Menagerie for 1950 production (Palmer \& Bray, 2009, p. 46 and 299).

The collaboration of Williams and Hollywood has been the focus of New Historic scholarship. Did the adaptability mean that Williams and Hollywood were communicating with audience through homogeneous discourse or they shaped different but complementary discourses? This article tried to answer the question by illustrating the hows and whys of Williams's process of adaptation. It would be interesting to mention that both Williams and Hollywood challenged the categorization and genre definition of art: they ceased to be one-discourse bound.

\section{HOW PCA AND HOLLYWOOD DISCOURSES MEET}

Discussing Hollywood of the 50s would be impossible if Williams's adaptations had to be put aside. Both Williams and Hollywood had this reciprocal relationship to shape each other's fame, artistic prestige and marketability. Many prize winning and commercially successful films of the era could bear witness: A Streetcar Named Desire (Kazan \& Feldman, 1951), The Rose Tattoo (Mann \& Wallis, 1955), Baby Doll (Kazan, and Kazan \& Williams, 1956), Cat on a Hot Tin Roof (Brooks \& Weingarten, 
1958), Suddenly, Last Summer (Mankiewicz \& Spiegel, 1959), Summer and Smoke (Glenville \& Wallis, 1961) and The Night of the Iguana (Huston, and Huston \& Stark, 1964). It seemed that restraint, decorum, self-discipline and moderation were imposed by movie regulations in the 50s and 60s. The letter-fights in New York Times of the 50s is the very proof of that claim where diverse ideologies and discourses collided such as Williams, Kazan (i.e.: Williams's adaptation and stage director), Breen (the martinet head of the PCA) and Wald (Glass Menagerie producer). PCA (Production Code Administration), Hays Office Code, Joseph Breen, Legion of Decency and HUAC managers (House UnAmerican Activities Committee), wrongly translated 'decorum' to "repression, revision, sublimation [and] displacement" (Wood, 2003, p. 43). On the other hand, Hollywood always claimed to visualize unrestrained energy, controversiality and true feeling which were never to be allied with self-discipline, moderation and even decorum. It seemed that what Hollywood claimed and advertised as its favorite discourse was standing in sharp contrast with that of PCA. Yet, a deeper study proved another reality read between the lines of PCA's codes: the rejected and the accepted ones.

Wood (2003) declared that the 'decorum' of Hollywood was "to a great degree artificially imposed" by the powerful, "dominant ideology [of] Hays Office Code," HUAC and PCA (p. 43). HUAC was mostly in charge of political issues in America during the Cold War era. No film, literature or any type of art could advertise communism. No Hollywoodian could be of such profession or be connected with it. HUAC was leading a devoted campaign to drive the Reds out of television, radio, Broadway and Hollywood since they made "screen, radio and TV, Moscow's most affective Filth Column in America"; the Red ideology was "poisoning the minds of [American] children under [their] very eyes" ("Hollywood blacklist"). To reinforce HUAC's discourse, PCA was specifically erected to curb and monitor the visual form and content of movies.

The treatise of Motion Picture Production Code was divided into six parts, twelve sections, thirty nine titles and ninety six subtitles (!) discussing the whys and hows of the prohibition (Leff, \& Simmons, 2001, pp. 285-300). The forbidden subjects had a very long list from dressing codes to killing a policeman on screen: 1- Crimes against the Law, 2- Sex (e. g. Scenes of Passion, Seduction, White-slavery, Miscegenation and Actual Child Birth were forbidden), 3- Vulgarity, 4- Obscenity, 5- Profanity, 6- Costume (e. g. Provocative Clothes, Undressing Scenes, Indecent or
Undue Exposure were not allowed) 7- Dances, 8Religion (i. e. Ministers of Religion mustn't be depicted as comic characters or villains), 9- Locations associated with sin were inadmissible, 10- National Feelings had to be carefully and respectfully treated, 11- Title of the picture had to show the ethical practices of an honest business, 12- Repellent Subjects (e.g. Actual Hangings, Brutality, Branding of people or animals, the Sale of Women and even Surgical Operations had to be removed).

Though sensationalism was an important issue in PCA, the Code showed great decorum and care for genre definition. The codes discussing the careful depiction of 'Religion', 'National Feelings', the prohibition of 'Crime against Law' and 'Repellant Subjects' have been obeyed. Even if they've been broken like Detective Story (Wyler, 1951), the films were not such a great critical and financial success compared with the sensational adaptations of Williams. What Hollywood objected mest and twisted most, were only the Codes related to sensuality. Therefore, only those codes that followed the desired discourse of Hollywood were retained, the rest were shrewdly neglected. So, was Hollywood as unorthodox and controversial as it claimed? In its zest for the portrayal of unrestrained passion and feeling, 'yes', Hollywood tried to shape discursive discourse; however, in its being strictly genre-conscious, 'no', Hollywood reinforced PCA's discourse. This genre categorization of films existed even in the pre-code era. Contrary to Wood's (2003) belief, decorum has long existed in Hollywood.

Historically, the disrepute of the Code from the mid Twentieth until the early Twenty First Century was mostly limited to its orthodox curtailing of sexuality while other discourses regarding Religion, Crimes against the Law or National Feeling were hardly discussed, and thus were marginalized. After the "twelve-year ban of cop-killing on screen" was wiped away by Detective Story (Wyler, 1951), critics didn't consider Wyler's code-breaking as bold as what Elia Kazan did in Streetcar Named Desire (1951) (Leff \& Simmons, 2001, p. 198). It seemed as if nothing was equal to the passion, sensation and 'raw electricity' that Streetcar brought for audience which always indicated highbrow, yet notorious subject matters associated with Williams (Palmer \& Bray, 2009, pp. viii, $1,12,15,77,86,89,94,104,106,123,128,134$, 148, 180, 191, 243, 245 and 260). In another Williams's adaptation, The Rose Tattoo (Mann \& Wallis, 1955), most Italians were pictured as buffoons, mildly including the Italian priest, which was another deviation from the Code (i.e. National Feeling and Religion). However, it wasn't counted as 
code-departure compared with the carnal and pagan love of a woman for a man (Serafina for Rosario and later for Alvaro).

Film historians declared that sexuality was possible only if portrayed in the mold of marriage and family values. Nevertheless, many directors embedded eroticism in a symbolic foil. In Williams's adaptation, the forbidden rape in Streetcar (Kazan \& Feldman, 1951) was represented in Stanley's breaking of Blanche's reflection on mirror with a phallic bottle and later the fierce washing of the street with water hose. The fornication in Baby Doll (Kazan, and Kazan \& Williams, 1956) was represented in Silva's sleeping on Baby Dolls bed and his wild horse-riding while drinking the lemonade he previously offered to Baby Doll. In The Fugitive Kind (Lumet, and Jurow $\&$ Shepherd, 1959), besides meaningful gazes and pointed dialogues, the copulation was hinted when Lady Torrance offered Valentine Xavier a room with the picture of a nude lady which both admired greatly. In Suddenly, Last Summer (Mankiewicz \& Spiegel, 1959) homosexuality was represented in the scantly clad male pictures decorating Sebastian Venable's room and the beach boys who were under Sebastian/ camera's gaze; cannibalism was represented in the hungry looks of the beach boys approaching Sebastian and trapping him on a cliff.

Ironically, in religious setting, celebrating eroticism was much easier. Literally and figuratively, The Ten Commandments (DeMille, and DeMille \& Wilcoxon, 1956) and Samson and Delilah (DeMille, 1949) looked far more amorous in their flimsy foil of religion. It would be interesting to mention that the director, Cecil B. De Mille, used to be a member of The Production Committee (i.e. the Hollywood Jury).

Thus, neither history was as objective as it seemed to be and nor were the Codes as strict as history claimed. That fact, surely echoed Boney's (1994) definition of "revisionist history" (p. 196); that how we narrated history and why we revised our narrations were more important than what actually happened (Morales, 1993, p. 101).

\section{HOW WILLIAMSIAN ENDING IS TRIMMED BY HOLLYWOOD}

Williams's being merely subversive and controversial didn't win him fame and appreciation. His works has been tamed by Hollywood audience and PCA codes. He was so displeased with his first Hollywood adaptation in the 1950, The Glass Menagerie (Rapper, and Feldman \& Wald, 1950), that he wanted to abandon the whole idea (Palmer \& Bray, 2009, p. 26). However, he gave consent to many cinematic representations of his plays until he was alive. Ten television adaptations were broadcasted from 1947 to the 1984 version of Streetcar, which had Williams's blessing though aired after his death; nine foreign adaptations for television, theatrical release, and the small screen from 1954 to 1981 were produced; most significantly, fifteen Hollywood adaptations from Glass Menagerie (1950) to Last of the Mobile HotShots (Lumet, 1970) were shining on the silver screen (Palmer \& Bray, 2009, pp. 275-285). After all, why Williams contradicted himself? Did he want to be shopped on Hollywood window or not, despite losing his Williamsian brand to a Hollywoodian label?!

In the early 50s, when he was (inter)nationally recognized as an acclaimed playwright, Williams came to Hollywoodian epiphany that films stayed much longer than play production: "I'm afraid that my plays will be remembered mostly by films made of them" (Devlin \& Tischler, 2004, p. 538). Ironically, he argued that in "film[s], you're much less certain of [the authorship]" (Williams, 1960, p. 3). Though he seemed reluctant, even abhorrent, to embrace his sudden burst into fame in the prologueessay "The Catastrophe of Success" (1948), he has been "writing with such an experience [of fame] in mind" (1045); he informed readers of the public misunderstanding that "many people [were] not willing to believe that a playwright [was] interested in anything but popular success" (ibid.). Surely, Hollywood spectacle could magnify that popularity. That was why he had to sacrifice a faithful adaptation for the sake of an "entirely new . . . cinematic [creation]" (Devlin, 1986, pp. 70-71) or as Hutcheon (2006) optimistically named it: "Creative Interpretation/Interpretive Creation" (p. 18, emphasis in the original). Williams wanted the popularity of Hollywood celebrity as well as the artistic aura of stage. Merging the binary oppositions of decorumconscious, PCA-affected Hollywood movie and uncensored art cinema, which were two very different domains in the 50s, seemed impossible. Their assimilation needed compromises, sacrifices and disillusionment on the side of Williams, which he halfheartedly welcomed to embrace Hollywood popularity.

His plays were moderated, most obviously in their ending, to fit the PCA discourse that many Hollywood producers, directors and audience approved of. Yet, this enforced, and sometimes unfittingly inserted happy ending was not merely the outcome of censorship imposed by PCA, Joseph Breen, Legion of Decency, HUAC, Hays Office Code and the rest of organized powers who tried to take percussions against the emergence of subversive discourse. 
Many times, Hollywood bent or even broke the Codes and the bowdlerizing regulations. One can refer to the previous discussion in this article about the symbolic, religious and even literal depiction of the forbidden subjects. It seemed that the box-office was the cornerstone of the film industry. In the 50s, boxoffice was a complex network of directors, stars, acclaimed novelists and dramatists as scriptwriters, independent producers hunting controversial plots and the runaway Hollywood audience.

Hollywood was not in its heyday of the mid 40s any more. Weekly film attendance was reduced to fifty percent because of the popularity of TV, censorship and the growing suburban population (Leff \& Simmons, 2001, p. 194). However, Hollywood tried to lure audience to box-office promising adult, Freudconscious, sensuous films much different with unchallenging programs in the small screen of conservative TV (Klinger, 1994, p. 40). One of the filmmakers in the 50s told Variety that '[w]e've found the way to get across an interesting idea involving Marilyn Monroe or Jane Russell, but without being boldly indecent about it" ("We've found the way", 1953, p. 37).

In the 50s, the C-rated films ("Condemned") were alluring for many filmgoers. Some critics claimed that beneath the gray flannel suit and ready-to-wear chaste midi-skirts of the decade, lurked "an America that yearned to cast off the rigid sexual bonds" (Leff \& Simmons, 2001, p. 211). In 1953, Playboy was born; on the other hand, in 1954, The Comics Code Authority banned the sadistic, sexual, criminal and violent topics in comic books which entirely ruined the business (Sarracino \& Scott, 2008, pp. 60-62). Fredric Wertham's (1954) influential book, The Seduction of the Innocent had the most dynamic position in shaping the Code. He argued that children's eyes were unwisely opened up to crime and psychosexual adult subjects which was a prologue to juvenile delinquency. Comics Code Authority was openly reinforcing the PCA's discourse. In the 50s, both passionate Playboyish and restrained PCAish discourses were advertising for communication. And if the communication was not possible, they tried to send a one-way message. Under the banner of PCA, lived a disciplined, refined, ethical but bigoted America; under the banner of Playboy, art film and comic books, another America sang of psychosexual liberalism, maturity and the scorn for modesty. Williams, of course, belonged to the second version of America and that was the pre-sold quality of his adaptation which magnetized Hollywood. By the early $70 \mathrm{~s}$, sex and violence themes were an inseparable part of American film industry (Brook, 2001 , p. 359 , Sklar, 1976, p. 296).
In addition to subverting the sensual codes of PCA, Hollywood mildly subverted political regulation of HUAC. Used-to-be communists or gray-listed actors like Edward G. Robinson played villains to prove that they've returned to the warm arms of America (Lev, 2003 , p. 164). The HUAC blacklisted movie artists like Joseph Losey or Dalton Trumbo lived a prolific life in exile by making European Art movies or script writing under fronts and pseudonyms; sometimes, they even won Academy Awards (i.e. American Oscar) (Lev, 2003, p. 156, "Joseph Walton Losey", and "Dalton Trumbo"). To save their carriers, directors like Elia Kazan gave testimony before HUAC against some of their fellow artists whose names weren't new to the court. To serve the boxoffice, they subverted PCA rules to a great extent by utilizing Williamsian themes (Brook, 2001, pp. 347359, Kazan, 1988, p. 449 and 564, Hirschorn, 1979, p. 326).

In Williams's adaptation of the 50s, many shots had been taken and retaken, some shots had been cut then replaced by the metaphoric and symbolic appearance (rape in Streetcar [1951], adultery in Baby Doll [1956] and The Fugitive Kind [1959], anthropophagy and homosexuality in Suddenly, Last Summer [1959]). Thus, if audience wanted Williamsian ending, they could have it in one way or another.

Nevertheless, a clear-cut answer for the audiences' cinematic preference seemed impossible since Hollywood of the 50s didn't give many genre choices. If there were no PCA and HUAC rules, what would be the outcome? One might claim that the critics and the moviegoers of the 50s as well as the New Historicist of the $21^{\text {st }}$ century would praise the Williamsian tension and uncertainty reflected in his open endings and plastic theater exactly as the critics and audience of Broadway did from the 50s onward. Yet, it's a partial conclusion. Clue-finding in the absence of any alternative in Williams's adaptations of the 50s or any redux version looked so demanding. Actually, all the studies were bound to history. They mostly covered the interviews with directors, producers and Williams and their struggles to bend or eliminate the Codes. What-if-there-were-no-Code is the gap in academic studies regarding Hollywood of the 50s.

Furthermore, only the box-office was not the representation of audiences' wants and wills. The postwar ideology had an influential role to popularize the philosophy behind film production. With the American opulence in the 50s, the media declared that the rise of American standard of living was "three times as high as the Britons, six times as high as the Italians [and] eleven times as high as the Turks" 
(Miller, 1958, p. 476). Now, Americans narrated a new version of history: "[f]rom their bounty, Americans had fed Europe after two World Wars and aided the Russians during a period of starvation" (Conter, Ezell, \& Fite, 1957, p. 313). It looked as if The Great Depression (1929-39) and the Wall Street crash was erased out of the historical memory of the United States.

The Great Depression and War had to be forgotten so that Americans would embrace the luxury of the 50s. The postwar era needed to propagate a quest to transcend the brooding memories of war and pessimism. Hollywood spectacle could easily augment the Williamsian joys of life and human dignity despite loss. Hollywoodian Williams appeared to be a less ambiguous concretization of the so-called hope for the used-to-happy-ending audiences. And for more sophisticated audiences of art cinema, the adaptations could safely land on the ground of a meaningful resolution and promise (Palmer \& Bray, 2009, p. 273, Taubman, 1962, p. 49, Yacowar, 1977, p. 94). Therefore, the power play represented in PCA Codes, Hollywood's subversion and reinforcement of those codes, Williams's rise and decline of stage and cinematic fame, moviegoers' box-office choice and the postwar ideology well manifested Foucault's illustration of power relations. In this complicated network of subversion and reinforcement, no institution or person can moderate everything according to its wants and will.

\section{CONCLUSION}

History can be written as one fact or recognized as a series of flexible "fictions"! That's what Hollywood did by exploring, revising and interpreting Williams as 'adaptation(s)'. Thus "historical scholarship involv[ed] the (re)examination of facts, or the unearthing of new facts (often suppressed), which resulted in a foundation for new interpretations" (Boney, 1994, p. 196). Hollywood's claim for unorthodoxy, unrestrained energy and disdain for decorum, PCA's struggle to keep discipline and restrictions and Williams's identity as an artist and a Hollywoodian were all (re)examined and challenged in this article.

Boney's (1994) "revisionist history" (p. 196) was of great help to illustrate the New Historicist methodology. It claimed that history often reflected the period in which it was written more than the period it covered. 'Revisionist history' privileged the inspection of ideology and cultural or material context over experimental and observed data. The focus was on the contemporary meanings that any text could or would create. Though Williams's adapted plays, mostly mean to reflect the late $30 \mathrm{~s}$ and $40 \mathrm{~s}$, they were the iconic representation of the ideology and discoursefights in the 50s (i.e. PCA and Hollywood opposetion).

With the lens of revisionism and re-visitism, this article illustrated the relativity of Williams and his adaptations, their being dialogic and not onediscourse bound. If Williams's works did not have the potentiality to yield to those PCA codes accepted by Hollywood and moviegoers, they would never be adapted. Thus, Hollywood's choice for adaptation, Williams's writing and the changes in his adaptations were an extremely political act of writing history as a tool of power to revise the culture of their time more than the culture of future or past.

According to Foucauldian concept of power, it "is not something that can be acquired, seized, or shared"; power "is exercised from innumerable points, in a set of unequal, shifting relations. [It] comes as much from below as from above" (Sheridan, 1980, p. 184). PCA and HUAC were not as powerful as they seemed sitting on the throne of regulating system. Hollywood and Williams had skewed their authority in many ways. That was how they partly reinforced and partially subverted the powerful discourse of their time.

\section{REFERENCES}

Boney, B. (1994). Review of the communists, cowboys, and queers: The politics of masculinity in the work of Arthur Miller and Tennessee Williams. TDR (1988-1994), 38 (3, Autumn), 196-201.

Bradley, B. (2011, July 16). American cultural history: 1950-59. Lone Star College - Kingwood. Retrieved from www.kclibrary.lonestar.edu. decade $50 . h t m l$

Brook, V. (2001, October). Courting controversy: The making and selling of Baby Doll and the demise of the Production Code. Quarterly Review of Film and Video, 18(4), 347-360.

Brooks, R. (Director) \& Weingarten, L. (Producer). (1958). Cat on a hot tin roof. [DVD]. United States: MGM.

Conter, R., Ezell, J. \& Fite, G. (Eds.). (1957). Readings in American history: 1865 to the present. Vol. 2. ( $2^{\text {nd }}$ ed.). The Riberside Press: Boston.

DeMille, C. B. (Director), \& DeMille, C. B. \& Wilcoxon, H. (Producers). (1956). The ten commandments. [DVD]. United States: Paramount Pictures. 
DeMille, C. B. (Director \& Producer). (1949). Samson and Delilah. [DVD]. United States: Paramount Pictures.

Devlin, A J. (Ed.). (1986). Conversations with Tennessee Williams. Jackson: Univ. Press of Mississippi.

Devlin, A J., and Tischler, N. (Eds.). (2004). The selected letters of Tennessee Williams, volume II. New York: New Directions.

Glenville, P. (Director) \& Wallis, H. (Producer). (1961). Summer and smoke. [DVD]. United States: Paramount Pictures.

Hirsch, F. (1979). A portrait of the artist: The plays of Tennessee Williams. N.Y. and London: National University Publications and Kennikat Press.

Hirschorn, C. (1979). The Warner Brothers story. New York: Crown.

Hollywood blacklist. (n.d.). Americans don't patronize reds!!!! [Tract]. Retrieved June 27, 2011, from http://en.wikipedia.org/wiki/Hollywood_blacklist.

Huston, J. (Director) \& Huston, J. \& Stark, R. (Producers). (1964). The night of the iguana. [DVD]. United States: MGM and Seven Arts Productions.

Hutcheon, L. (2006). A theory of adaptation. New York: Routledge.

James Dalton Trumbo. (n.d.). Retrieved July 23, 2011, from http://en.wikipedia.org/wiki/James Dalton Trumbo.

Joseph Walton Losey. (n.d). Retrieved July 31, 2011, from http://en.wikipedia.org/wiki/JosephWalton Losey

Kazan, E. (1988). Elia Kazan: A life. New York: Alfred Knopf.

Kazan, E. (Director) \& Feldman, C. (Producer). (1951). A streetcar named desire [DVD]. United States: Warner Brothers Pictures.

Kazan, E. (Director) and Kazan, E. \& Williams, T. (Producers). (1956). Baby doll [DVD]. United States: Newtown Productions.

Klinger, B. (1994). Melodrama and meaning: History, culture, and the films of Douglas Sirk. Bloomington: Indiana Univ. Press.

Leff, L. \& Simmons, J. (2001). The dame in the kimono: Hollywood, censorship, and the production code. $\left(2^{\text {nd }}\right.$ ed.). Lexington: Univ. Press of Kentucky.

Lev, P. (2003). Hollywood international. In P. Lev. (Ed.). The Fifties: Transforming the screen, 1950-1959 (Vol. 7, pp. 147-168). New York: Charles Scribner's \& Sons.
Lumet, S. (Director), and Jurow, M., \& Shepherd, R. (Producers). (1959). The fugitive kind [DVD]. United States: United Artists.

Lumet, S. (Director). (1970). Last of the mobile hot shots [DVD]. United States: Warner Bross.

Mankiewicz, J. (Director) \& Spiegel, S. (Producer). (1959). Suddenly, last summer. [DVD]. United States: Columbia Pictures.

Mann, D. (Director) \& Wallis, H. (Producer). (1955). The rose tattoo. [DVD]. United States: Paramount Pictures.

Miller, W. (1958). A history of the United States. Dell Publishing Co, Inc.: New York.

Morales, E. (1993, September 28). Small circle of friends. Village Voice, pp. 100-101.

1950's famous people. (2009). Retrieved June 25, 2011, from www.challengefashion.com/1950sfamous-people.

Palmer, B., \& Bray, W. (2009). Hollywood's Tennessee: the Williams films and postwar America. $\left(1^{\text {st }}\right.$ ed.). University of Texas Press: Austin.

Playboy. (n.d). Retrieved October 30, 2009, from http://en.wikipedia.org/wiki/Playboy

Rapper, I. (Director) and Feldman, C. \& Wald, J. (Producers). (1950). The glass menagerie. [DVD]. United States: Warner Bros.

Sarracino, C. \& Scott, K. (2008). The porning of America: The rise of porn culture, what it means, and where we go from here. Boston, Massachusetts: Beacon Press.

Sheridan, A. (1980). Michel Foucault: The will to truth. New York: Tavistock Publications.

Sklar, R. (1976). Movie-made America. New York: Vintage Books.

Taubman, H. (1962, January 7). Changing course. New York Times, 49.

We've found the way. (1953, February 4) Variety, p. 37.

Wertham, F. (1954). Seduction of the innocent: The influence of comic books on today's youth. New York and Toronto: Rinehart and Company Inc.

Williams, T. (1960). Interview by Dick Leavitt. Showbill: The Program Magazine for Particular Moviegoers. New York: Newcastle. p.3.

Wood, R. (2003). Hollywood from Vietnam to Reagan and beyond. New York and West Sussex: Columbia University Press.

Wyler, W. (Director \& Producer) (1951). Detective story. [DVD]. United States: Paramount.

Yacowar, M. (1977). Tennessee Williams and film. New York: Ungar. 